\title{
Analyzing the Academic Research Trends by Using University Digital Resources: A Bibliometric Study of Electronic Commerce in China
}

\author{
Anam Fatima ${ }^{1, *}$, Asad Abbas ${ }^{1}$, Wan Ming ${ }^{1}$, Ahmad Nawaz Zaheer ${ }^{2}$, Masood-ul-Hassan Akhtar \\ ${ }^{1}$ School of Public Affairs, University of Science and Technology of China, Hefei, 230026, Anhui province, People's Republic of China \\ ${ }^{2}$ Department of Business Administration, Government College University Faisalabad, Sahiwal Campus, Pakpattan Rd, Sahiwal, Pakistan \\ ${ }^{3}$ Capital FM Private Limited, 1st Floor, Umer Building, 76 West Blue Area, Islamabad, Pakistan
}

Copyright $\bigcirc 2017$ by authors, all rights reserved. Authors agree that this article remains permanently open access under the terms of the Creative Commons Attribution License 4.0 International License

\begin{abstract}
Technology plays a vital role in every field of life especially in business and education. Electronic commerce (EC) begins in the year of 1991 right after internet was introduced for commercial use [1]. It is known to be the 12th five years' plan (2011 to 2015) of Chinese Ministry of Industry and Information Technology. The main objective of this study is to highlight the latest academic research trends on different topics or themes of EC in China by using university digital resources that is digital library. In order to obtain these latest academic trends, we have conducted bibliometric study and collected data from digital library for last six years i.e. from 2010 to 2015 . The main motivation to choose this research topic and China was the worldwide reputation of this country, as top EC country in the world due to its high number of online users, and also impact of five years' Chinese government EC plan and policy. So, due to these facts we have established our research questions related to EC research trends in China to explore the answer of our Research Question: What are the latest research trends in the field of electronic commerce in China since 2010? As we wanted to know the answer thus we collected data through digital library and analyzed them fully to get a brief outlook about this EC trend. Result showed that a lot of research was already conducted on EC topics in China on different themes during the said duration. We can conclude that, this research trends showed that EC is a potential research field in China due to government five year EC policies or plan and to promote IT culture in Chinese society. This research provides guideline to the government IT policy makers and also academia researcher to be more focused on few topics or themes, where China is lacking behind, as leading EC country in the world.
\end{abstract}

Keywords Academic, Education, Research Trends, Digital Resources, Business, Electronic Commerce, E-commerce, China

\section{Introduction}

In modern era, governments in both developed and developing countries trying to adopt information and communication technologies (ICT's) by doing some reforms in their ICT policies related to business and education. From last few decades, it has been notice all around the world that most of the research universities and colleges are now focusing on adoption of latest technologies. So, they can improve quality of education and help their students by providing access of digital resources which contributes in the field of educational research. By achieving latest technologies, all stakeholder get benefits from it such as government, universities, and society. According to the 2014 UN e-government survey, population wise China is the first largest country in the world as for e-government it is ranked 70 worldwide and eighteen out of twenty countries in Asia [2].

The world's largest traditional library in United States has 120 million manuals (in form of paper) resources in more than 460 different languages. Digitalization of resources is very new concept and has short history. The concept of future digital resources was introduced in 1965, and that time it was predicted that in future digital resources will be very innovative, its access and application also different as compare to traditional resources for example traditional libraries. Academic research literature has an evidence about development of digitization of processes. Digital resources or e-resources is evidence of it. In 1990s, researcher explore new field related to digitalization of resources [3]. First example of digitization of resources is the first ever project was started to convert manual or print resources to digital one. Vatican Library Accessible World is prime example. For digitalization of Vatican Library, three partner organizations form Brazil, Italy and USA were involved to 
digitize all collection of printed papers and books [4].

Digital resources facilitate the users to access resources electronically through internet [5]. Especially research community is the largest user of digital resources. Along with usage research from IT field are also contributing in it. The purpose of contribution is improving the speed and easy to access from different location such as work or home. According to some scholars, digital resources has only one that is online which only make difference as compare to traditional or manual resources [6]. Online or digital resources are the combination of other digital resources which are connect through network and have digital form of data i.e. articles and e-books which facilitate users to access digital form of data from different $[3,7]$.

Electronic commerce (EC) begins in the year of 1991, right after internet was introduced for commercial use [1]. EC was based on the web-based information technologies to computerize business processes including transaction, work flow, buyers, sellers, products information and services through computer based network. Rapid development in ICT and EC facilitates customers to use online services and purchase new goods [8]. EC is on the 12th five-year plan (2011 to 2015) of Chinese Ministry of Industry and Information Technology with a goal to make China an e-commerce global leader. China is the largest e-commerce country in the world according to the total number of online user. In the end of 2013, users of internet in China quickly approached to 600 million, a high trend of internet usage is being observed in recent past year in China and this pattern is expected to increase to $75 \%$ till 2015 , perhaps enabling factors if not properly given due attention, may not reach desired goals. In China 55\% of internet users pay through mobile and by 2015 e-business transactions in China and projected to hit USD 540 billion. Four main factors of EC growth in China compromised of EC, social media, digital payments and mobile devices [9-11]. Geographically China is the important country for analysis of EC development in term of business and emerging market and rapidly growing economy. It is important to identify the key business factors during transformation and also proper planning or strategy of available resources in business [12]. EC led development of economy is the part of vision of the Chinese government which will foster efficiency and boost economic development [13]. According to Benbasat et al. [14], nine main research topics in the field of electronic commerce (EC), those are 1) strategic issue 2) Assessment/ valuation 3) organizational transformation and societal issue 4) Adoption issue 5) Theory and methodology 6) Marketing and CRM issue 7) Technical issue 8) Security and legal issue, and 9) Logistics/ Operations.

\subsection{Motivation and Objective of the Study}

From last few years, mode of education research has been change and now the traditional university research education is moved to modern one that is university digital resource.
Due to these changes, all academic research scholars are using digital resources (university digital libraries) to get latest information about new research fields and trends. It is also being noticed that a lot of research studies related to education, information technology, social and management sciences are based on literature reviews. The purpose of these studies is to find the literature gap and fill it by using new tools and techniques and also to explore new emerging field of studies as well. According to Lei et al. [15], a large number of studies has been conducted in Chinese language about e-commerce in China based on systemic literature review. There is no specific in-depth systemic literature based study is conducted on E-commerce in China to highlight the Chinese government last $12^{\text {th }}$ five years' plan and its effects. The motivation to choose EC academic research trends topic and China was the reputation as top EC country in the world due to high number of online users to sale and purchase their goods through interne and also impact of five years' Chinese government EC plan. A large number of studies has been conducted on e-commerce in general and more specifically published in (English language) foreign journals [15]. The main objective of this bibliometric study is to highlight the effects of Chinese government policies on e-commerce by exploring through university digital resources to find out latest academic research trends of EC towards development, adoption and acceptance in China. So, due to these changes we have established our research question related to $\mathrm{EC}$ educational research trends in China to explore the answer of our Research Question: What are the latest educational research trends in the field of electronic commerce in China since 2010? through university digital resources based literature review of last five year (from 2010 to 2015).

\section{Research Methodology}

For this study, we have conducted literature review because it provides important information about research areas, especially helps in the theory development and also research gaps where more work is required [16]. Before conducting any literature review, brainstorming, formation of keywords, searching material on internet (scientific search engines) and databases, time duration (period) for data collection are important elements [16-18]. During literature review, data can be analyzed of three or four year times [19]. So, we collected and analyzed all data from 2010 to 2015. According to Li et al. [20], there are four important steps to carry out any literature review 1) define paper inclusion/ exclusion criteria, identifying the research domain and choose specific keywords for searching, 2) searching and refine the sample collected through available 3 ) analyze the text material according to selected study and 4) for representation and categorize and structure the data for review and should be rigor and relevance [20, 21].

We have chosen keywords from Benbasat et al. [15] 
research topics in electronic commerce (EC) for our research studies. After selection of keywords, we made a combination of these keywords with 'electronic commerce', 'e-commerce', 'China' including Benbasat et al. [15] research topics as a keyword during search of data within science technology and social science domain as given in figure 1.

\subsection{Data Collection and Analysis Process}

After finalizing the research topic, we have established our research question and then design data collection process model. Data collection process model is known to be used for collecting data on databases. Figure 1 showed that research question is linked with brainstorming whereas brainstorming is linked with both research question and formation of keywords. After the formation of keywords, we started data collection or information gathering from University databases.

During data collection, first we selected research domain that was science technology, and social sciences. After that we select time period (starting and ending year), and then enter different combination of keywords. By the combination of different keywords, we get outcome in the form of published papers in different journals and conferences during the period of $2010-2015$.

For this study, we collected/search data related to our research question from digital library databases. We used Google scholar for our initial concepts related to selection of research topic and question. For, data collection we used university digital resources that is Web of Science database because it contains journals and conference papers of science technology and social sciences domain.

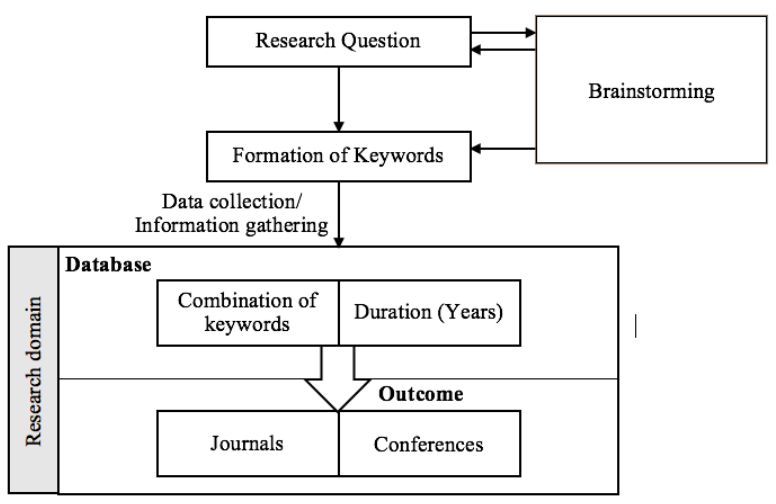

Figure 1. Data collection process model [16, 17]

Our paper selection criteria for this study was to select only those articles which are published in journal and conference and also listed in Web of Science database within period of 2010 to 2015. By using clustering and theory creating method of Grönlund and Andersson [16, 21], we wrote all themes mentioned in selected articles (from both journals and conferences) and then we grouped them with respect to each main topic. For analysis of the academic research trends, categorize and structure data for review [20]. So, we categorized all collected data in tabular form which represents main topic and also trends related to publications both type-wise (journal of conference) and also year-wise as well.

\section{Results and Discussion}

After data collection and analysis of collected data, result showed that a lot of academic research was conducted on EC topic in China on different themes since 2010. Academic research trends on different domain of e-commerce demonstrate that still more work is required to improve e-commerce in China by carrying out more studies on marketing and CRM, transformation, valuation, security and privacy issue. In recent days, these are very important research topics to improve quality of e-commerce services and also ensure to security of online personal data. As show in Table 1, total number of papers published (2010 - 2015) on EC theme in context of China are 447 on 13 different research topics. The list of different e-commerce research themes is listed below:

\subsection{Strategy Issues}

Academic researches, are based on strategy issue in e-commerce to cover the inadequate infrastructure, information leakage, transaction fraud related to online payment, security technology, corporate social responsibility, telecommunication and m-commerce companies in formation marketing [22-24].

\subsection{Adoption Issue}

Issues to adopt e-commerce in China are limited infrastructure of internet, language barrier, electronic payment issues, industrial structure and irregular business processes, customer behaviour, unproven technology (such as information errors), and quality improvement of financial information are core issue in adoption of electronic commerce [25-27].

\subsection{Theory and Methodology}

From collected data, it has been noticed a list of theories and methodologies used for electronic commerce research. Such as:

Theory: "Social capital theory and social network theory". Method: "Large data set collected from an e-commerce platform" [28].

Theory: "Customer satisfaction theory, information and decision making theory and self-efficacy theory". Method: "Questionnaire and partial least squares structural equation modelling" [29].

Theory: "Grounded in traditional technology adoption and information diffusion theories". Method: "Exploratory research approach, including interviews and further 
analysis from published sources" [24].

Theory: "Information systems success theory, the technology acceptance model, and trust theory as theoretical bases". Method: "Questionnaire survey, the structural equation modelling technique" [30].

\subsection{Technical Issue}

In China, technical issues in the field of e-commerce are integrity and security issues, transaction platform, web-based marketing, logistics, payment, and technical support [31-34].

\subsection{Security and Legal Issue}

Security and legal are also critical in the field of e-commerce such as cybercrime and security, trade issues, transmission of information through technology and construction of security systems, safe and convenient application environment, information security including data encryption, authentication and firewall technology, and also legal protection measures [35-37].

\subsection{Marketing and CRM Issue}

It is emerging research topic in e-commerce and the list of issues related to e-commerce are e-supply chain capability, e-CRM, performance and process of co-creating business value [38].

\subsection{Logistics}

Logistics is one of an important and key element of e-commerce. Literature shows that in-depth is already been done on this topic such as service level and overall cost, RFID technology, logistic time, third party logistics (3PL) enterprises, develop transportation standardization, integration and networking, and propose new requirements for freight background operation mode, logistics service quality, e-commerce logistics evaluation system, e-commerce logistics distribution system, new logistics mode (fourth-party logistics management), logistics alliance platform to improve speed of produce transportation of specific improvement strategy, regional logistics informatization, lack of socialization, supply of particular logistics, demand and capacity by modern logistics industry development, logistics integration of e-market and key technologies, building collection and delivery point (CDP), logistics inventory and automation operation based on RFID technology, poor infrastructure, low level IT, high cost of logistics distribution, and management personnel shortage, third party e-commerce platform (super-business center concept includes e-trading market, third party guarantees payment, and third party logistics) [39-55].

\subsection{Operations}

Lack of customer information, price plans, sales, management, product data, regulate EC market environment and promote its healthy operation, electronic system of distribution (ESD), business operations and internal management provides high quality of services to the customer, information sharing for demand-side supply, transport integrated with operation, employed OLAP technology for improvement of management and logistic industry [24, 56-58].

\subsection{Assessment}

Online auditing performance assessment, enterprise e-commerce evaluation index system, fuzzy cluster analysis, fuzzy comprehensive evaluation methods, strategy of green marketing, information serving, transaction processing, supporting technology and website operation, personal credit assessment [55, 59-61].

\subsection{Social Issue}

In China, social issues related to e-commerce are information seeking, expressive, and sharing, and social interaction, stronger influence on consumers' social commerce intentions, consumers' adoption and networking services, social information browsing, social development $[23,62,63]$.

\subsection{Transformation Issue}

Transformation faces issue in e-commerce are supply chain management, optimum use of all resources [64].

\subsection{Organization Issue}

Political, culture, human capital, technology issues include cyber-security, knowledge dissemination, advancement, sharing deals, and generation [37, 65].

Table 1. EC in China research themes during data collection (from 2010 to 2015)

\begin{tabular}{|c|c|}
\hline Keywords & Result \\
\hline Strategy issue & 25 \\
\hline Adoption issue & 14 \\
\hline Theory and methodology & 20 \\
\hline Technical issue & 09 \\
\hline Security and legal issue & 07 \\
\hline Marketing and CRM issue & 02 \\
\hline Logistics & 157 \\
\hline Operations & 123 \\
\hline Assessment & 32 \\
\hline Valuation & 05 \\
\hline Social issue & 34 \\
\hline Transformation issue & 02 \\
\hline Organization issue & 17 \\
\hline Total & $\mathbf{4 4 7}$ \\
\hline
\end{tabular}

Research trends also showed that during selected period of time most of the academic research was conducted on logistics and operation themes with 157 and 123 papers 
respectively whereas less number of researches was conducted on Marketing and CRM and transformation issues as shown in Table 1. Year-wise 118 papers published in both conference and journal during 2010 which attained maximum number in that year, whereas less number of papers published in 2015 which was 4 .

Table 2 shows that high number of publications are 39 on logistics in 2013, and 0 is the lowest number of publications in many themes such as strategy (2015), adoption (2015), technical (2015), security and legal (2012, 2014 and 2015), marketing \& CRM (2010, 2011, 2012, 2013, and 2015), social (2015), transformation (2011, 2012, 2013, 2014, 2015), and organizational issue (2015); theory and methodology (2015); assessment (2015); valuation (2011, 2014, and 2015).

Table 2. Year wise EC in China research themes during 2010 to 2015

\begin{tabular}{|c|c|c|c|c|c|c|}
\hline $\begin{array}{c}\text { Year } \\
\text { Keywords }\end{array}$ & 2010 & 2011 & 2012 & 2013 & 2014 & 2015 \\
\hline Strategy issue & 7 & 3 & 9 & 5 & 1 & 0 \\
\hline Adoption issue & 1 & 4 & 2 & 2 & 5 & 0 \\
\hline $\begin{array}{c}\text { Theory and } \\
\text { methodology }\end{array}$ & 7 & 3 & 2 & 7 & 1 & 0 \\
\hline Technical issue & 4 & 2 & 1 & 1 & 1 & 0 \\
\hline $\begin{array}{c}\text { Security and legal } \\
\text { issue }\end{array}$ & 1 & 4 & 0 & 2 & 0 & 0 \\
\hline $\begin{array}{c}\text { Marketing and } \\
\text { CRM issue }\end{array}$ & 0 & 0 & 0 & 0 & 2 & 0 \\
\hline Logistics & 33 & 27 & 26 & 39 & 30 & 2 \\
\hline Operations & 36 & 28 & 27 & 24 & 6 & 2 \\
\hline Assessment & 13 & 7 & 6 & 3 & 3 & 0 \\
\hline $\begin{array}{c}\text { Valuation } \\
\text { Social issue }\end{array}$ & 1 & 0 & 2 & 2 & 0 & 0 \\
\hline $\begin{array}{c}\text { Transformation } \\
\text { issue }\end{array}$ & 2 & 0 & 0 & 0 & 0 & 0 \\
\hline $\begin{array}{c}\text { Organization } \\
\text { issue }\end{array}$ & 8 & 1 & 3 & 2 & 3 & 0 \\
\hline
\end{tabular}

Maximum number of papers published in conference i.e. 294 as compare to journals i.e. 153 during last five years with percentage of $66 \%$ in conference and remaining $34 \%$ in journals as showed in table 3 and 4 respectively.

Table 3. Percentage wise list of published papers related EC in China research themes during 2010 to 2015

\begin{tabular}{|c|c|}
\hline Conference & Journals \\
\hline $66 \%$ & $34 \%$ \\
\hline
\end{tabular}

During search, 91 papers were found which was published in 2010 and only 4 papers were published in the year of 2015 and in case of journal maximum papers found during 2013 with total number of 62 and less number of papers are ' 0 ' in 2015.
Table 4. Year wise list of published papers related EC in China during 2010 to 2015

\begin{tabular}{|c|c|c|c|c|c|c|}
\hline$\#$ & 2010 & 2011 & 2012 & 2013 & 2014 & 2015 \\
\hline Conference & 91 & 74 & 52 & 29 & 44 & 4 \\
\hline Journal & 27 & 17 & 35 & 62 & 12 & 0 \\
\hline
\end{tabular}

Every year a large number of academic conferences are arranged by Chinese universities with sponsors of some well renowned publishers such as IEEE. The purpose of these conferences is to gain revenue and also provide platform to Chinese research scholars to bring their innovative ideas in the form of conference papers. These conference papers highlighted the latest Chinese research academic topic and also published as conference proceeding under the flagship of publishers and university as an organizer. For publication in journals, Chinese university scholars are not fluent in English language due to most of the university higher education programs and also research is in Chinese language. Due language barrier and also strict criteria of journal peer review process effects on publication as well.

Overall objective of this paper is only to highlight the trends of academic related to e-commerce during 12th five years' Chinese government plan. In this research studies, we will not cover influence factors which effects on e-commerce related topics in China. Although according to academic research trends of collected data shows that some themes/topics are newly emerge related to e-commerce, which is the main reason for lacking behind with compare to others topics.

\section{Conclusion}

We can conclude that most of the academic research work related to electronic commerce in China has been published on logistics topic and least number of researches was found to be on marketing and CRM issue, and transformation issue from last six years is available on university digital resources. So, digital resources based studies is helpful in analyzing academic research trends. This type of research study provides guidelines to the Chinese government IT policy makers to promote IT culture in a society and to focus on the few areas where research shows that government need to adopt upcoming new IT policy. For keep EC top ranked country in the world, Chinese government need to work on valuation; security, legal, strategy and adoption issue.

\subsection{Limitations}

The aim of the study was to identify and highlight the EC research trends in China from Chinese government IT policy and five years' plan through university digital resources. So, for this study we collected data related to list of themes or topics and analyzed according to our main research topic. The limitation of this study was the limited scope of our research. Furthermore, if we have more time then we can expand our duration of data collection from five years to ten 
years. So, this will give us the clear scenario of EC research trends and its rapid development and acceptance in China.

\subsection{Future Work}

This study highlights the research trends in the field of EC in China, and also gives guideline to Chinese government IT policy makers and academia researchers to consider different areas where EC is lacking behind. Anyone can do further extend this research as EC research policy in China and EC research trends in both developed and developing countries in context of challenges and opportunities.

\section{Appendix}

Combination of keywords during searching data (from 2010 to 2015)

\begin{tabular}{|c|c|}
\hline Keywords & Result \\
\hline Electronic Commerce + Strategy + issue + China & 10 \\
\hline E-Commerce + Strategy + issue + China & 15 \\
\hline Electronic Commerce + adoption + issue + China & 6 \\
\hline E-Commerce + Strategy + issue + China & 8 \\
\hline $\begin{aligned} \text { Electronic Commerce }+ & \text { Theory and Methodology }+ \text { issue } \\
& + \text { China }\end{aligned}$ & 5 \\
\hline E-Commerce + Theory and Methodology + issue + China & 15 \\
\hline Electronic Commerce + technical + issue + China & 1 \\
\hline E-Commerce + technical + issue + China & 8 \\
\hline Electronic Commerce + Security + legal + issue + China & 4 \\
\hline E-Commerce + Security + legal + issue + China & 3 \\
\hline Electronic Commerce + Marketing + CRM + issue + China & 1 \\
\hline E-Commerce + Marketing + CRM + issue + China & 1 \\
\hline Electronic Commerce + logistics + China & 56 \\
\hline E-Commerce + logistics + China & 101 \\
\hline Electronic Commerce + operations + China & 46 \\
\hline E-Commerce + Operations + China & 77 \\
\hline Electronic Commerce + Assessment + issue + China & 5 \\
\hline E-Commerce + Assessment + issue + China & 27 \\
\hline Electronic Commerce + Valuation + China & 1 \\
\hline E-Commerce + Valuation + China & 4 \\
\hline Electronic Commerce + Social + issue + China & 16 \\
\hline E-Commerce + Social + issue + China & 18 \\
\hline Electronic Commerce + transformation + issue + China & 1 \\
\hline E-Commerce + transformation + issue + China & 1 \\
\hline Electronic Commerce + organization + issue + China & 5 \\
\hline E-Commerce + organization + issue + China & 12 \\
\hline Total & 447 \\
\hline
\end{tabular}

\section{Acknowledgements}

The first author (Anam Fatima) is thankful to Chinese government (Chinese Scholarship Council - CSC scholarship) for providing financial support during Master's research studies.

\section{REFERENCES}

[1] Land E-c. History of E-commerce 2004 [Available from: www.ecommerce-land.com/history_ecommerce.html.

[2] UN E-GS. Government Survey 2014 [Available from: https:/ /publicadministration.un.org/egovkb/en-us/Reports/UN-E-Go vernment-Survey-2014.

[3] Abbas A, Faiz A. Usefulness of digital and traditional libraries in higher education. International Journal of Services Technology and Management. 2013;19(1-3):149-61.

[4] Pavani AM, editor The role of digital libraries in higher education. International Conference on Engineering Education, Rio de Janeiro, Brazil

http://wwwineerorg/Events/ICEE2007/papers/637pdf; 2007.

[5] Khan N, Kumari D, Firdaus S. Usage of Information Sources by PG Students of Social Science Faculty, AMU: A Survey. Journal of Advances in Library and Information Science. 2015;4(2):129-34.

[6] Jack NC. How library science students use digital libraries 2009 [Available from:

http://www.slideshare.net/nicholascjackson/library-science-st udents-anddigital-libraries.

[7] Lee GT, Dahlan N, Ramayah T, Karia N, Hasmi Abu Hassan Asaari M. Impact of interface characteristics on digital libraries usage. Malaysian Online Journal of Instructional Technology. 2005;2(1):1-9.

[8] Lai J-Y. E-SERVCON and E-Commerce Success: Applying the DeLone and McLean Model. Web Design and Development: Concepts, Methodologies, Tools, and Applications: IGI Global; 2016. p. 816-38.

[9] MacGregor RC, Vrazalic L. A basic model of electronic commerce adoption barriers: A study of regional small businesses in Sweden and Australia. Journal of small business and enterprise development. 2005;12(4):510-27.

[10] Stanley T, Ritacca R. E-commerce in China: Driving a new consumer culture. KPMG Report. 2014.

[11] Statista-Dossier. Statistics and facts about e-commerce in China 2014 [Available from:

http://www.statista.com/topics/1007/e-commerce-in-china.

[12] Tan J, Tyler K, Manica A. Business-to-business adoption of eCommerce in China. Information \& management. 2007; 44(3): 332-51.

[13] Martinsons MG. Electronic commerce in China: emerging success stories. Information \& Management. 2002; 39(7): $571-9$.

[14] Benbasat I, Piccoli G, Ives B. Research topics in e-commerce 2010 [Available from: http://ceit.aut.ac.ir/ sa_hashemi/My\%20Research/0-Selected \%20Papers/2-ECommerce\%20Systems/RESEARCH\%20TO PICS\%20IN\%20E-COMMERCE.pdf. 
[15] Lei Z, Fen L-X, Wei W-H, editors. Domestic E-commerce research topics evolution analysis. International Conference on Management e-Commerce and e-Government (ICMeCeG), 2012 International Conference on; 2012: IEEE.

[16] Abbas A, Faiz A, Fatima A, Avdic A, editors. Reasons for the failure of government IT projects in Pakistan: A contemporary study. Service Systems and Service Management (ICSSSM), 2017 14th International Conference on; 2017: IEEE.

[17] Scupola A, Islam MS. E-service research trends in the domain of e-Government: A Contemporary Study. International Journal of E-Services and Mobile Applications. 2011.

[18] Webster J, Watson RT. Analyzing the past to prepare for the future: Writing a literature review. MIS quarterly. 2002:xiii-xxiii.

[19] Chua CEH, Straub DW, Khoo HM, Kadiyala S, Kuechler D. The evolution of e-commerce research: A stakeholder perspective. Journal of Electronic Commerce Research. 2005;6(4):262.

[20] Li L, Gao P, Mao J-Y. Research on IT in China: a call for greater contextualization. Journal of Information Technology. 2014;29(3):208-22.

[21] Grönlund Å, Andersson A, editors. e-Gov research quality improvements since 2003: more rigor, but research (perhaps) redefined. International Conference on Electronic Government; 2006: Springer.

[22] Chong AY-L, Chan FT, Ooi K-B. Predicting consumer decisions to adopt mobile commerce: Cross country empirical examination between China and Malaysia. Decision Support Systems. 2012;53(1):34-43.

[23] El-Haddadeh R, Weerakkody V, Peng J. Social networking services adoption in corporate communication: the case of China. Journal of Enterprise Information Management. 2012;25(6):559-75.

[24] Chen WY, editor Information sharing framework for the integrated collaborative operation in through transport of railway freight. Applied Mechanics and Materials; 2013: Trans Tech Publ.

[25] Liu C, Yao LJ, Sia CL, Wei KK. The impact of early XBRL adoption on analysts' forecast accuracy-empirical evidence from China. Electronic Markets. 2014;24(1):47-55.

[26] Yang S, Cao Y, Mao W, Zhang R, Luo L, editors. Determinants of behavioral intention to mobile payment: Evidence from China. Advanced Information Management and Service (ICIPM), 2011 7th International Conference on; 2011: IEEE.

[27] Zhou W, editor B2b e-commerce adoption in developing countries: A chinese study. Information Technology, Computer Engineering and Management Sciences (ICM), 2011 International Conference on; 2011: IEEE.

[28] Qu Z, Wang Y, Wang S, Zhang Y. Implications of online social activities for e-tailers' business performance. European Journal of Marketing. 2013;47(8):1190-212.

[29] Zha X, Li J, Yan Y. Information self-efficacy and information channels: Decision quality and online shopping satisfaction. Online Inform Rev. 2013;37(6):872-90.

[30] Zhou T. Examining the critical success factors of mobile website adoption. Online Inform Rev. 2011;35(4):636-52.
[31] Qiu J. The Security and Prevention of E-Commerce in China. Advanced Research on Computer Science and Information Engineering: Springer; 2011. p. 162-5.

[32] Tao W, editor Evaluation and Construction of Individual credit evaluation system Based on third-party e-commerce transaction platform. E-Business and E-Government (ICEE), 2010 International Conference on; 2010: IEEE.

[33] Yanqiu D, Xueping L. On E-commerce Integrity Security and Technical Support.

[34] Hongbo Y, Gaojun H, editors. Study on the E-Commerce in Zhejiang: A Case Study of Yi Wu Non-woven Handbags. Conference: International Conference on Information Technology and Industrial Engineering; 2010; Wuhan.

[35] Dong YH, Li W, Guo XW, editors. A study on the security issues and solution of electronic commerce. Advanced Materials Research; 2011: Trans Tech Publ.

[36] Wang L, Zou C, Zhang S, editors. A study on the commerce security characteristics for electronic business. E-Business and E-Government (ICEE), 2010 International Conference on; 2010: IEEE.

[37] Kshetri N. Cybercrime and cyber-security issues associated with China: some economic and institutional considerations. Electronic Commerce Research. 2013;13(1):41-69.

[38] Jiang Y, Zhao J. Co-creating business value of information technology. Industrial Management \& Data Systems. 2014;114(1):53-69.

[39] Zu Q, Sun B, editors. Optimization of Order Picking Work Flow at the E-commerce Logistics Centers. International Conference on Human Centered Computing; 2014: Springer.

[40] Wu CY, Lan L, Ding F, Zhao X, editors. Overview of RFID Technology Based on Green Logistics in China. Applied Mechanics and Materials; 2014: Trans Tech Publ.

[41] Kuang Y, Luo X, Yu Y, editors. Kunming cut flowers e-commerce Logistics Development Strategies. Management of e-Commerce and e-Government (ICMeCG), 2014 International Conference on; 2014: IEEE.

[42] Xia Z, Hong X, Miao Z, Chen D, Zhang J, editors. Asymmetric evolutionary game between $\mathrm{B} 2 \mathrm{C}$ ecommerce enterprises and the 3PL enterprises in China. Service Systems and Service Management (ICSSSM), 2014 11th International Conference on; 2014: IEEE.

[43] Zeng J. Process Re-Engineering of Railway Freight Logistics. ICLEM 2014: System Planning, Supply Chain Management, and Safety2014. p. 299-304.

[44] Lin Y, Luo J, Zhou L, Ieromonachou P, Huang L, Cai S, et al., editors. The impacts of service quality and customer satisfaction in the e-commerce context. Service Systems and Service Management (ICSSSM), 2014 11th International Conference on; 2014: IEEE.

[45] Feifei W. Study on E-commerce Logistics Evaluation System Optimization Strategy from The Perspective of Service Encounter. Journal of Convergence Information Technology. $2013 ; 8(6)$.

[46] Hong X, Jingjing Q, Xingli T. B2C E-commerce vehicle delivery model and simulation. Information Technology Journal. 2013;12(20):5891. 
[47] Li Z, editor The Situation, Problems and Trends of E-Commerce Logistics Management in China. Applied Mechanics and Materials; 2013: Trans Tech Publ.

[48] Lihua W, editor Post-crisis era of SMEs management innovation in E-commerce. Information Management, Innovation Management and Industrial Engineering (ICIII), 2013 6th International Conference on; 2013: IEEE.

[49] Zhao S, Liang W, Han D, editors. Seaport logistics information sharing platform in e-commerce: A case study of QDIP in China. Internet (AH-ICI), 2012 Third Asian Himalayas International Conference on; 2012: IEEE.

[50] Qu H-z, Dong N, editors. Analysis on the opportunities and risk which the logistics of e-business rise to the credit business of commercial bank. Industrial Engineering and Engineering Management (IE\&EM), 2011 IEEE 18Th International Conference on; 2011: IEEE.

[51] Huang L, Yu P, Luo Q, Yu G, editors. Construction of Chinese new rural e-commerce platform and its key technologies research based on double E-markets. Mechatronic Science, Electric Engineering and Computer (MEC), 2011 International Conference on; 2011: IEEE.

[52] Xu J, Hong L, Li Y, editors. Designing of collection and delivery point for e-commerce logistics. Information Technology, Computer Engineering and Management Sciences (ICM), 2011 International Conference on; 2011: IEEE.

[53] Luo Z, Wang H, editors. Research on intelligent supermarket architecture based on the Internet of Things technology. Natural Computation (ICNC), 2012 Eighth International Conference on; 2012: IEEE.

[54] Lujing L, editor The dilemma and way out faced by the logistics industry in China under e-commerce conditions. Business Management and Electronic Information (BMEI), 2011 International Conference on; 2011: IEEE.

[55] Tao W, editor Research on the Construction of e-Business Center Based on Value Chain. E-Product E-Service and E-Entertainment (ICEEE), 2010 International Conference on; 2010: IEEE.
[56] Ye SQ, editor A Research on the Enterprises Information Management Based on E-Commerce. Applied Mechanics and Materials; 2013: Trans Tech Publ.

[57] Teng Y, editor Application Research of Computer Technology in the Decision Making of China's Supermarket Logistics Centers. Advanced Materials Research; 2012: Trans Tech Publ.

[58] Jia L, Lujing X. Study on China telecom billing-side real-time information and data synchronization. Telecommunications science. 2014;30(5):145-50.

[59] Chen W, Smieliauskas WJ, Liu S-f, editors. Performance assessment of online auditing in China from the perspective of audit cost control. Systems Man and Cybernetics (SMC), 2010 IEEE International Conference on; 2010: IEEE.

[60] Cheng F, Li W, editors. An evaluation on the e-commerce internet marketing function of Jiangxi local municipal governments' official tourism websites. Information Science and Engineering (ICISE), 2010 2nd International Conference on; 2010: IEEE.

[61] Sunxu, Haixia. E-commerce extension multi-factor assessment. Innovative computing and information: ICCIC 2011, PII; 2011. 484-91 p.

[62] Yang X, Li G-x, editors. Exploring social commerce adoption in China: A uses and gratification perspective. Management Science \& Engineering (ICMSE), 2014 International Conference on; 2014: IEEE.

[63] Zhao S, editor Research of the Modern Rural Logistic System Construction. e-Education, e-Business, e-Management, and e-Learning, 2010 IC4E'10 International Conference on; 2010: IEEE.

[64] Ke L, Li-ying W, editors. Transformation of Station and Function of Tourist Attraction in China Based on Supply Chain Management Theory. Management of e-Commerce and e-Government (ICMeCG), 2010 Fourth International Conference on; 2010: IEEE.

[65] Wang J-F. E-commerce communities as knowledge bases for firms. Electronic Commerce Research and Applications. 2010; 9(4):335-45. 